\title{
EDITORIAL
}

\section{In This Issue: Tools to Help Focus on What is Valuable}

\author{
Kurt C. Stange, $M D, P b D$, Editor
}

Ann Fam Med 2017;15:402-404. https://doi.org/10.1370/afm.2145.

$\mathrm{T}$ his issue brings to light tools and techniques to help clinicians, patients, and policy makers focus on what is important amidst a cacophony of competing demands.

The prioritizing function in primary care $^{1-3}$ is one of the underappreciated reasons why health care systems that support primary care have healthier populations, greater health equity, and more sustainable costs. ${ }^{4}$ The way of the generalist begins with a broadly inclusive gaze and an investment in relationships..$^{5-8}$ The generalist scans patients' acute complaints, life events, multiple chronic illnesses, and health promotion and disease prevention opportunities within family and community context, in order to put attention on the particulars ${ }^{9}$ that might do the most good in the moment. ${ }^{10}$ The generalist then raises the gaze to act on each particular from the perspective of its larger context. ${ }^{11-13}$ Usually this involves iteratively re-prioritizing and then providing care for multiple problems ${ }^{14,15}$; sometimes it involves coordinating care within an otherwise fragmented system. ${ }^{16,17}$ The articles in this issue can help with the prioritizing function that is under-recognized, undervalued, but vital.

Shaughnessy and colleagues develop and evaluate the Guideline Trustworthiness, Relevance and Utility Scoring Tool. "G-TRUST" appears to be useful for helping clinicians identify which among an overabundance of clinical guidelines might be helpful in informing care for their patients. ${ }^{18}$ In an accompanying editorial, LeFevre notes that although guidelines were developed to make it easier to bring science to clinical care, the glut of guidelines developed by consensus panels is actually moving us backwards toward authority-based medicine. ${ }^{19}$

In an article featured in Annals Journal Club, Arndt and colleagues use electronic health record event log data and time-motion observations to identify areas for improvement in supporting family physicians' allocation of time for patients. They find that more than onehalf of a physician's 11.4 -hour work day is spent in the electronic health record-both during and after clinic hours. Nearly one-half of this time is spent in clerical and administrative tasks. ${ }^{20}$ Join the moderated Annals
Journal Club Twitter chat (\#AJC), on Wednesday October 4 at 12:00 pm EST / 16:00 GMT.

A potential solution to this dilemma, or at least a patch on the problem, is evaluated in a clinical trial by Lin et al. They randomize family physicians to alternating weeks with and without an electronic health record scribe. Having a scribe improves physician satisfaction with face time with patients, time spent with charting, and charting accuracy, while having no effect on patient satisfaction, and increasing the proportion of charts that were closed within 48 hours. ${ }^{21}$

Growing interest in population health ${ }^{22-35}$ is limited by practical methods for applying its principles in practice. ${ }^{26,29-31,33,36,37} \mathrm{~A}$ special report by Kaufman and colleagues reports on how the concept of "health extension" is manifested in practical ways by Cooperative Extension Services in several US states. This report shows how initial skepticism and protectionism can be overcome with shared priority setting, decision making, and funding from new sources, and through developing practical collaborative projects that build personal relationships and trust. ${ }^{38}$

To focus their attention on high-risk patients, practices use 4 methods, according to Reddy and colleagues. In their study of practices participating in the Comprehensive Primary Care (CPC) initiative developed by the US Centers for Medicare and Medicaid Services with the intention of strengthening primary care, practices stratify their patient populations by using: practicedeveloped algorithms, AAFP clinical algorithms, payer claims or electronic health record methods, and clinical intuition. ${ }^{39}$ These different approaches may have complementary strengths and weaknesses.

It is important to develop both systems and personal habits that minimize risks to patient safety. In a study of incident reports, Cooper et al find a high rate of blame and retribution. ${ }^{40} \mathrm{~A}$ focus on blame is likely to get in the way of identifying opportunities for learning and for systems improvement.

Two studies in this issue help us to focus on the needs of adults with developmental or intellectual disabilities. Carey et al, in a large study of patients from 343 general practices in the United Kingdom, find that adults with intellectual disabilities are at high risk of 
preventable emergency hospital admissions. ${ }^{41}$ A research brief by Havercamp and colleagues amplifies these findings by discovering that people with developmental disabilities have disparities in health status, quality of care, access, utilization, and unmet health care needs. ${ }^{42}$

Focusing on patients at high risk and at teachable moments are common strategies in primary care. A study from UK general practices finds that all risk factors are not created equal. General practitioners are less likely to support smoking cessation in patients with lung, bladder, and upper aerodigestive tract cancer than coronary heart disease, and patients with cancer are less likely to stop smoking. ${ }^{43}$

In a study of 870,319 community health center patients, Holderness et al find a very interesting pattern of large and unequal reductions in the rate of uninsurance in 10 states that expanded Medicaid and 6 states that did not. ${ }^{44}$

This issue continues the new Annals feature on Innovations in Primary Care. ${ }^{45,46}$ The innovations in this issue include a novel office-based opioid treatment program developed by an interdisciplinary team at a regional health and education center ${ }^{47}$ and a Massive Open Online Course (MOOC), available free to all who have Internet access, that educates participants about falls and fall prevention. ${ }^{48}$

We also are delighted to introduce the first virtual issue of Annals of Family Medicine. A virtual issue curates previously published articles, and draws new meaning from their collective content by bringing them together with a new editorial. This inaugural virtual issue addresses the intersection of clinical primary care and public health. ${ }^{49}$ The groundbreaking introductory editorial by Orkin et al uses the term Clinical Population Medicine to describe the "application of population health approaches to care for individual patients and design health care systems." ${ }^{\text {50 }}$

We welcome you to join the online discussion for each of the articles at http://www.AnnFamMed.org.

\section{References}

1. Stange KC. A science of connectedness. Ann Fam Med. 2009;7(5): 387-395.

2. Stange KC, Fedirko T, Zyzanski SJ, Jaén CR. How do family physicians prioritize delivery of multiple preventive services? J Fam Pract. 1994;38(3):231-237.

3. O'Connor PJ, Sperl-Hillen JM, Margolis KL, Kottke TE. Strategies to prioritize clinical options in primary care. Ann Fam Med. 2017; 15(1):10-13.

4. Starfield B, Shi L, Macinko J. Contribution of primary care to health systems and health. Milbank Q. 2005;83(3):457-502.

5. Bolen SD, Stange KC. Investing in relationships and teams to support managing complexity. J Gen Intern Med. 2017;32(3):241-242.

6. Scott JG, Cohen D, Dicicco-Bloom B, Miller WL, Stange KC, Crabtree BF. Understanding healing relationships in primary care. Ann Fam Med. 2008;6(4):315-322.
7. Soubhi H, Bayliss EA, Fortin M, et al. Learning and caring in communities of practice: using relationships and collective learning to improve primary care for patients with multimorbidity. Ann Fam Med. 2010;8(2):170-177.

8. Beach MC, Inui T; Relationship-Centered Care Research Network. Relationship-centered care. A constructive reframing. J Gen Intern Med. 2006;21(Suppl 1):S3-S8.

9. McWhinney IR. 'An acquaintance with particulars...'. Fam Med. 1989;21(4):296-298.

10. Stange KC. The generalist approach. Ann Fam Med. 2009;7(3): 198-203.

11. Stange KC. Refocusing knowledge generation, application, and education: raising our gaze to promote health across boundaries. Am J Prev Med. 2011;41(4)(Suppl 3):S164-S169.

12. Stange KC. In this issue: raise the gaze. Ann Fam Med. 2014;12(5): 398-399.

13. Frankel RM, Saleem JJ. "Attention on the flight deck": what ambulatory care providers can learn from pilots about complex coordinated actions. Patient Educ Couns. 2013;93(3):367-372.

14. Stange KC, Zyzanski SJ, Jaén CR, et al. Illuminating the 'black box'. A description of 4454 patient visits to 138 family physicians. J Fam Pract. 1998;46(5):377-389.

15. Bolen SD, Sage P, Perzynski AT, Stange KC. No moment wasted: the primary-care visit for adults with diabetes and low socio-economic status. Prim Health Care Res Dev. 2016;17(1):18-32.

16. Bodenheimer T. Coordinating care-a perilous journey through the health care system. N Engl J Med. 2008;358(10):1064-1071.

17. Stange KC. The problem of fragmentation and the need for integrative solutions. Ann Fam Med. 2009;7(2):100-103.

18. Shaughnessy AF, Vaswani A, Andrews BK, et al. Developing a clinician-friendly tool to identify useful clinical practice guidelines: G-TRUST. Ann Fam Med. 2017;15(5):413-418.

19. LeFevre ML. From authority- to evidence-based medicine: are clinical practice guidelines moving us forward or backward? Ann Fam Med. 2017;15(5):410-412.

20. Arndt BG, Beasley JW, Watkinson MD, et al. Tethered to the EHR: primary care physician workload assessment using EHR event log data and time-motion observations. Ann Fam Med. 2017;15(5):419-426.

21. Gidwani R, Nguyen C, Kofoed A, et al. Impact of scribes on physician satisfaction, patient satisfaction, and charting efficiency: a randomized controlled trial. Ann Fam Med. 2017;15(5):427-433.

22. Starfield B. Basic concepts in population health and health care. J Epidemiol Community Health. 2001;55(7):452-454.

23. Barr VJ, Robinson S, Marin-Link B, et al. The expanded Chronic Care Model: an integration of concepts and strategies from population health promotion and the Chronic Care Model. Hosp Q. 2003;7(1):73-82. http://www.longwoods.com/content/16763.

24. Friedman DJ, Starfield B. Models of population health: their value for US public health practice, policy, and research. Am J Public Health. 2003;93(3):366-369.

25. Kindig D, Stoddart G. What is population health? Am J Public Health. 2003;93(3):380-383.

26. Gulliford MC, Jack RH, Adams G, Ukoumunne OC. Availability and structure of primary medical care services and population health and health care indicators in England. BMC Health Serv Res. 2004;4(1):12.

27. Mabry PL, Olster DH, Morgan GD, Abrams DB. Interdisciplinarity and systems science to improve population health: a view from the NIH Office of Behavioral and Social Sciences Research. Am J Prev Med. 2008;35(2)(Suppl):S211-S224.

28. Maeshiro R. Responding to the challenge: population health education for physicians. Acad Med. 2008;83(4):319-320. 
29. Neuwelt P, Matheson D, Arroll B, et al. Putting population health into practice through primary health care. $N$ Z Med J. 2009;122(1290):98-104.

30. Zenzano T, Allan JD, Bigley MB, et al. The roles of healthcare professionals in implementing clinical prevention and population health. Am J Prev Med. 2011;40(2):261-267.

31. Committee on Integrating Primary Care and Public Health of the Board on Population Health and Public Health Practice. Primary Care and Public Health: Exploring Integration to Improve Population Health. Washington, DC: National Academies Press; 2012.

32. Institute of Medicine. Primary Care and Public Health: Exploring Integration to Improve Population Health. Washington, DC: National Academies Press; 2012.

33. Hacker K, Walker DK. Achieving population health in accountable care organizations. Am J Public Health. 2013;103(7):1163-1167.

34. Kringos DS, Boerma W, van der Zee J, Groenewegen P. Europe's strong primary care systems are linked to better population health but also to higher health spending. Health Aff (Millwood). 2013;32(4):686-694.

35. Kaplan GA, Diez Roux AV, Simon CP, Galea S. Growing Inequality: Bridging Complex Systems, Population Health, and Health Disparities. Washington, DC: Westphalia Press; 2017.

36. Northridge ME, Ellis JA. Applying population health models. Am J Public Health. 2003;93(3):365-411.

37. Folsom Group. Communities of solution: the Folsom Report revisited. Ann Fam Med. 2012;10(3):250-260.

38. Kaufman A, Boren J, Koukel S, Ronquillo F, Davies C, Nkouaga C. Agriculture and health sectors collaborate in addressing population health. Ann Fam Med. 2017;15(5):475-480.

39. Reddy A, Sessums L, Gupta R, et al. Risk stratification methods and provision of care management services in comprehensive primary care initiative practices. Ann Fam Med. 2017;15(5):451-454.
40. Cooper J, Edwards A, Williams H, et al. Nature of blame in patient safety incident reports: mixed methods analysis of a national database. Ann Fam Med. 2017;15(5):455-461.

41. Hosking FJ, Carey IM, DeWilde S, et al. Preventable emergency hospital admissions among adults with intellectual disability in England. Ann Fam Med. 2017;15(5):462-470.

42. Prokup JA, Andridge R, Havercamp SM, Yang EA. Health care disparities of Ohioans with developmental disabilities across the lifespan. Ann Fam Med. 2017;15(5):471-474.

43. Farley A, Koshiaris C, Oke J, et al. Physician support of smoking cessation after diagnosis of lung, bladder, or upper aerodigestive tract cancer. Ann Fam Med. 2017;15(5):443-450.

44. Angier $\mathrm{H}$, Hoopes $M$, Marino $M$, et al. Uninsured primary care visit disparities under the Affordable Care Act. Ann Fam Med. 2017;15(5):434-442.

45. Stange KC. In this issue: innovations in primary care and at the Annals. Ann Fam Med. 2017;15(3)202-203. http://www.annfammed. org/content/15/3/202.full.

46. Annals of Family Medicine [journal]. http://www.annfammed.org/ content/current\#InnovationsinPrimaryCare.

47. Wilson C, Fagan EB. Successful integration of office based opioid treatment into primary care. Ann Fam Med. 2017;15(5):481.

48. Frith J. Falls prevention: empowering people through online education. Ann Fam Med. 2017;15(5):482.

49. Annals of Family Medicine. Clinical Population Medicine [virtual issue]. http://www.annfammed.org/cgi/collection/clinicalpopulationmedicine. Accessed Aug 29, 2017.

50. Orkin A, Bharmal A, Cram J, Kouyoumdjian FG, Pinto AD, Upshur R. Clinical population medicine: integrating clinical medicine and population health in practice. Ann Fam Med. 2017;15(5):405-409. 